\title{
Five Times Yearly
}

National Cancer Institute

\section{Source}

National Cancer Institute. Five Times Yearly. NCI Thesaurus. Code C98851.

Five times per year. 